\title{
Combined effects of temperature and a pesticide on the Baltic amphipod Monoporeia affinis
}

\author{
Therese Jacobson $^{1, *}$, Andreas Prevodnik ${ }^{2}$, Brita Sundelin ${ }^{1}$ \\ ${ }^{1}$ Department of Applied Environmental Science, Stockholm University, 10691 Stockholm, Sweden \\ ${ }^{2}$ Department of Life Sciences, Södertörn University College, 14189 Stockholm, Sweden
}

\begin{abstract}
Effects of elevated temperature, in combination with exposure to the fungicide fenarimol, on reproduction in the deposit-feeding Baltic amphipod Monoporeia affinis were investigated. Previously, fenarimol was found to cause endocrine disruption in other crustacean species, via the ecdysteroid system. $M$. affinis were exposed to elevated temperature and/or fenarimol in soft-bottom microcosms during sexual maturation and mating. Elevated temperature and fenarimol $\left(0.7 \mathrm{mg} \mathrm{l}^{-1}\right)$ acted synergistically and increased the number of females with dead eggs, with a more than 4 -fold incidence compared to exposure to one of the stressors ( $24 \mathrm{vs.}<5 \%$ ). Exposure to both stressors also resulted in a negative intrinsic rate of increase, which might indicate a population decline in the field. Elevated temperature impaired sexual maturation in males and females, lowered the number of fertilised females, reduced fecundity and altered embryogenesis. Exposure to fenarimol resulted in a $40 \%$ decrease in ecdysteroid levels in sexually mature males and an increase in heat shock protein 60 expression. Ecdysteroid levels were not affected by temperature in either sex or stage of sexual maturation. Our results suggest that increase in the water temperature due to, e.g., global warming would impair reproduction and possibly increase the sensitivity of $M$. affinis to toxicants.
\end{abstract}

KEY WORDS: Monoporeia affinis · Endocrine disruption · Fenarimol · Temperature · HSP60 • Reproduction

\section{INTRODUCTION}

A recent model developed by the Rossby Centre in Sweden estimated the average temperature in the Baltic Sea, a brackish-water sea with low species diversity, to increase by $2.6^{\circ} \mathrm{C}$ by the year 2100 due to global warming (Meier 2002), with effects on hydrology and repercussions on biota. During most of the year the Baltic Sea is a stratified sea, but in spring and autumn water temperature shifts, with accompanying density changes and strong winds, mix the warm upper water layers with cold deeper layers.

This has consequences for bottom-dwelling organisms that have to adapt to seasonal temperature changes. One such organism is the amphipod Monoporeia affinis, a stenotherm coldwater detritus-feeder living on soft bottoms in the Baltic Sea. It has a sensi- tive period of gonad development during early to mid-autumn (for more details, see 'Materials and methods'), and then reproduces during late autumn and winter. Eriksson Wiklund \& Sundelin (2001) investigated effects of temperature increases on the embryogenesis of $M$. affinis. Their results showed that reproduction is most severely affected by temperature increases before mating, which normally occurs in late November, when elevated temperature due to water mixing is expected and both males and females migrate upwards in the water column (Donner et al. 1987).

Toxicant exposure narrows the thermal tolerance interval in animals (Cossins \& Bowler 1987). Furthermore, studies on the crayfish Procambarus clarkii have demonstrated that elevated temperature can increase the vulnerability of crustaceans to contaminant expo- 
sure, in this case heavy metals and the synthetic pyrethroid fluvalinate (Del Ramo et al. 1987, Sogorb et al. 1988). We hypothesised that elevated water temperatures during sexual maturation would negatively affect Monoporeia affinis, resulting in impaired reproduction and an increased vulnerability to contaminants. As a model substance we used fenarimol, a fungicide used in agriculture and e.g. on golf courses, Fenarimol has been reported to impair ecdysteroid synthesis in arthropods (Williams et al. 2000). Ecdysteroids are cholesterol derivatives controlling moulting and reproduction in insects and crustaceans (Subramoniam 2000). In particular, fenarimol (at $4 \mu \mathrm{M}$ ) has been shown to impair reproduction and embryogenesis in the cladoceran Daphnia magna (Mu \& Leblanc 2002,2004 ) and (at $2 \mu \mathrm{M}$ ) reduce the fertilisation frequency and the ability of males to fertilise females in M. affinis (Jacobson \& Sundelin 2006). Fenarimol has, to date, not been in commercial use in Sweden, and the amphipods used in the present study are not likely to have been pre-exposed to this fungicide.

Grabarczyk \& Kopec-Szlezak (1992) hypothesised a mechanism for fenarimol toxicity that involves the damaging levels of cellular oxidative stress from free radical formation. Oxidative stress may irreversibly modify protein amino acid side-chains into aldehyde or ketone groups (i.e. carbonylation), a situation that may result in protein aggregation, inactivation, or degradation (Levine et al. 1990). Such protein damage or modification, such as carbonylation, should result in the up-regulation of heat shock protein 60 (HSP60), a universal cellular response to protein damage (Feder \& Hoffmann 1999). HSP60 expression may also be under hormonal control, mediated through the immune system (Bajramović et al. 2000). Protein carbonylation is an established marker of oxidative stress in studies of human diseases (reviewed by Dalle-Donne et al. 2003) and ageing (e.g. Radák et al. 2002), although it has seldom been used in environmental contexts (see Almroth et al. 2005). Thus, this approach is still fairly new and has, to our knowledge, never been applied to crustaceans.

In the present study, we assayed a set of life-history and biochemical variables for Monoporeia affinis to broaden our understanding of the effects of elevated water temperatures and fenarimol exposure, and to explore the usefulness of these variables as biomarkers of contaminant exposure and/or thermal stress. The biochemical variables examined were (1) expression of HSP60 as a general stress indicator, (2) carbonylation level as an indicator of oxidative stress, and (3) ecdysteroid level as an indicator of endocrine disruption. The life-stage variables examined were (1) weight, (2) sexual maturation, (3) fertilisation, (4) fecundity, (5) dead eggs and (6) adult mortality.

\section{MATERIALS AND METHODS}

Test species. Monoporeia affinis is a cold-water amphipod inhabiting the soft bottoms of the Baltic Sea and inland lakes in Scandinavia. It is a deposit-feeding glacial relict with a life span of 1 to $4 \mathrm{yr}$, depending on surrounding conditions. Reproduction starts in early autumn when storage lipids from the spring bloom and the following summer feeding are allocated to the gonads and sexual maturation progress (Segerstråle 1937). Males undergo approximately 3 moultings during sexual maturation, with Stage III being the sexually mature male (authors' per. obs.). Mating begins in November; embryogenesis proceeds through the winter, and juveniles are released from the marsupium in February or March. M. affinis is semelparous; males die some weeks after mating, whilst spawned females can be observed a couple of months after juveniles are hatched and released from the marsupium (for details see Sundelin \& Eriksson 1998, Jacobson \& Sundelin 2006).

Experimental set-up. Adult Monoporeia affinis and sediment were collected using a benthic sled (position $59^{\circ} 16^{\prime} 943 \mathrm{~N}, 17^{\circ} 35^{\prime} 222 \mathrm{E}$, in Lake Mälaren) in early October and transported in cold water $\left(\sim 5^{\circ} \mathrm{C}\right)$ to the laboratory. They were then transferred to microcosms in groups of 50 adults microcosm ${ }^{-1}$, with an expected sex ratio of $1: 1$, to acclimate to each microcosm temperature for $13 \mathrm{~d}$ before initiation of the experiment. The freshwater flow-through, soft-bottom microcosms consisted of 21 Erlenmeyer flasks (flask bottom area $227 \mathrm{~cm}^{2}$ ) covered with green plastic film to simulate light at the bottom (20 to $30 \mathrm{~m}$ depth). An astronomical clock simulated the natural daylight regime. To prevent surface contact and escape of individuals, the outlets of the microcosms were covered with fine nets (mesh size $0.25 \mathrm{~mm}$ ). The microcosms had a bottom layer of $\sim 3 \mathrm{~cm}$ natural sediment, taken from the collection site and sieved (mesh size $0.5 \mathrm{~mm}$ ) to exclude juvenile $M$. affinis. To test for effects of elevated temperature $\left(4\right.$ vs. $\left.10^{\circ} \mathrm{C}\right)$ and fenarimol exposure (exposed vs. control), a $2 \times 2$ factorial design was applied with 12 microcosms treatment $^{-1}$ : (1) control individuals in low temperature (LTC), (2) fenarimol-exposed individuals in low temperature (LTF), (3) control individuals in warm temperature (WTC) and (4) fenarimol-exposed individuals in warm temperature (WTF). The temperature (for 1992 to 2005) at $40 \mathrm{~m}$ depth - the preferred habitat depth of $M$. affinis - at a field station (BY1) in the Trosa Archipelago in the Baltic Sea has been recorded as (average $\pm \mathrm{SD}$ ) $5.5 \pm 1.6,5.4 \pm 1.0,4.3 \pm$ $1.2^{\circ} \mathrm{C}$ in October, November, and December, respectively (Swedish Meteorological and Hydrological Institute, SHARK database www.smhi.se). The control temperature of $4^{\circ} \mathrm{C}$ was chosen as a reference temperature representing the present autumn water temperature. 
The experimental temperature of $10^{\circ} \mathrm{C}$ was chosen as a possible future autumn water temperature if the predictions of global warming, an increased water temperature at these conditions (40 $\mathrm{m}$ depth, autumn months) of $>2.6^{\circ} \mathrm{C}$, are accurate (Meier 2002).

Water flow-through was arrested once weekly for up to $24 \mathrm{~h}$, and $4.7 \mathrm{~g}$ pulverized Tetraphyll $\mathrm{m}^{-2}$ (Tetra), equalling one-fourth of the amount of organic carbon settling at spring bloom, and $0.675 \mathrm{mg} \mathrm{l}^{-1}(4.5 \mu \mathrm{M})$ fenarimol (Chem Service), in a $99.5 \%$ ethanol vehicle were administered. The ethanol concentration was $<0.05 \%$ in the microcosms. An equal amount of ethanol was administered to the control microcosms. The choice of concentrations was based on previous experiments and literature (see 'Introduction' for more details). The temperature and oxygen levels were measured (WTW Oxi 340) in 3 randomly selected microcosms each week before administration of the food and fenarimol and once again before resuming water flow. The microcosm water temperatures were (mean $\pm \mathrm{SD}$ ) $4.6 \pm 0.2$ and $10.7 \pm 0.3^{\circ} \mathrm{C}$, and the oxygen content was $9.9 \pm 1.1$ and $9.1 \pm 1.9 \mathrm{mg} \mathrm{l}^{-1}$ for the coldand warm-water treatments, respectively, throughout the experiment. Upon each occasion of food and fenarimol administration, the oxygen content decreased, whereupon it increased after the water flow was resumed. The experiment was terminated in midDecember after $9 \mathrm{wk}$ of exposure.

To test the concentration of fenarimol in the sediment, 2 sediment samples from each of the treatments LTC, LTF and WTF were randomly selected and analysed for fenarimol concentration. The samples were liquidextracted using dichloromethane, followed by a cleanup and determination using GC-MS (Analytica AB). The sediment fenarimol concentration was below the detection limit ( $<0.05 \mathrm{mg} \mathrm{kg}^{-1}$ dry wt) for the LTC after termination of the experiment. Final fenarimol concentrations $( \pm \mathrm{SD})$ were $0.5 \pm 0.06$ and $0.26 \pm 0.06$ for the LTF and WTF treatments, respectively.

Life-history variables. At the termination of the experiment, the amphipods were immediately analysed live under stereomicroscope $(80 \times$ magnification) for sexual maturation stage, presence and numbers of embryos, embryo developmental stage and abnormalities. Sexual maturation was determined after visual examination of external secondary sexual characteristics and gonad development (for a more detailed description, see Jacobson \& Sundelin 2006). Dead embryos, dead broods and dead oocytes were classified as 'dead eggs'. Afterwards, the animals were frozen and stored in the freezer $\left(-80^{\circ} \mathrm{C}\right)$ until biochemical analyses were performed. The intrinsic rate of increase for each microcosm was calculated using the formula:

$$
r=b-d
$$

where $r$ is the per capita intrinsic rate of increase, $b$ is the birth rate (here the per capita number of viable embryos) and $d$ is the per capita death rate.

Ecdysteroid analysis. Individuals from each microcosm were pooled into groups of 4 to 8 sexually mature males (Stage III), 5 to 9 sexually immature males (Stage I) and 7 to 8 females. A volume of ethanol approximately equal to 4 -fold the biovolume was added, and the sample was homogenized (RW20.n IKA Labortechnik), whereupon the homogenate was centrifuged at $4{ }^{\circ} \mathrm{C}$ at $20000 \times g$ for $10 \mathrm{~min}$. The supernatants were collected separately, and the pellets were washed with ethanol and centrifuged as above. Ecdysteroids were analysed using radioimmunoassay. The ecdysteroid antisera were produced by W. E. Bollenbacher (University of North Carolina, Chapel Hill, NC, USA) and kindly distributed to us by E. S. Chang (Bodega Marine Laboratory, Bodega Bay, CA, USA). The antibodies used are from the $2 \mathrm{~A}$ series; they detect ecdysone, 20-hydroxyecdysone, 3-dehydroecdysone and 25-deoxyecdysone. All samples were analysed according to Chang \& O'Connor (1979). Adaptations of the protocol and quality controls are described in Jacobson \& Sundelin (2006).

Protein extraction, Western blotting and expression quantification. Proteins were extracted from the amphipods using a buffer containing Tris- $\mathrm{HCl}$ (10 mM, $\mathrm{pH} 7.5), \mathrm{KCl}$ (12.5 mM), sucrose (500 mM), an antiprotease cocktail (Complete Mini, Roche) and 2\% w/v sodium dodecylsulphate (SDS), using slight prehomogenization with an electric hand-pestle and more complete homogenization with glass beads and a Mini BeadBeater (BioSpec). Total protein concentrations in the supernatants, collected after centrifugation for $10 \mathrm{~min}$ at $6000 \times g$ in a cold room at $6^{\circ} \mathrm{C}$, were determined with a modified Bradford assay (Biorad Protein Assay) for microplates. Prior to loading on gels, the proteins were solubilized in sample buffer containing sodium deoxycholate (1 $\mathrm{mM})$, triethanolamine $\mathrm{HCl}$ (5 $\mathrm{mM}), 2 \% \mathrm{w} / \mathrm{v}$ SDS and $5 \% \mathrm{v} / \mathrm{v} 2$-mercaptoethanol, $10 \%(\mathrm{v} / \mathrm{v})$. Electrophoresis was performed (14 $\mu \mathrm{g}$ heatdenatured protein well-loading ${ }^{-1}$ ) on Tris- $\mathrm{HCl} 7.5 \%$ gels (criterion-precasted gels, Bio Rad), followed by protein transfer onto polyvinylidene (PVDF) membranes (Pro Blot, Applied Biosystems) according to standard procedures. Separate gels were run for the 2 sexes and the male developmental stages, as it was impossible to separate all samples in a single gel. The PVDF membranes were cut horizontally into pieces spanning the molecular sizes of HSP60 and $\beta$-actin, the proteins of interest, as indicated by pre-stained molecular ladders (High-Range Rainbow Marker, Amersham Biosciences; Page Rule Prestained Protein Ladder SM0671, Fermentas). Non-specific binding sites were subsequently blocked with $10 \% \mathrm{w} / \mathrm{v}$ fat-free milk in 
phosphate-buffered saline (PBS) (pH 7.4) with $0.01 \%$ v/v Tween-20 for $1.5 \mathrm{~h}$ at room temperature. Probing with the HSP60 antibody (monoclonal anti-rabbit SPA 802, Nordic Biosite) and the $\beta$-actin antibody (polyclonal anti-rabbit H-300, Santa Cruz Biotechnology), diluted 1:125 and 1:100, respectively, in PBS (pH 7.4) with $0.01 \% \mathrm{v} / \mathrm{v}$ Tween-20 was done overnight at $6^{\circ} \mathrm{C}$. The membranes were washed and then probed with secondary antibodies (HRP-conjugated anti-mouse and anti-rabbit IG, DAKO, diluted 1:10000 in PBS [pH 7.4] with $0.01 \% \mathrm{v} / \mathrm{v}$ Tween-20) for $1 \mathrm{~h}$. After washing the membranes, the protein bands were visualized by means of enhanced chemiluminescence $\left(\mathrm{ECL}^{+}\right.$, Amersham Biosciences), and quantification of band intensities in arbitrary units (A.U.) in blot images (CCDcamera, Fuji LAS 1000) were done using the software Image Gauge 4.0 (Fuji). The HSP60 expression in sexually mature males (Stage III) was significantly altered (see 'Results'), thus, these samples were also analysed for carbonylation levels (oxidative protein modifications), to see if oxidative stress could explain this. Sexually mature male (Stage III) samples were derivatized for $20 \mathrm{~min}$ with $10 \mathrm{mM} \mathrm{2,4-dinitrophenylhydrazine}$ (DNPH) in $10 \%$ triflouroacetic acid, according to a method adapted from Lee \& Shacter (1995). By DNPH derivatization, 2,4-dinitrophenyl (DNP) is attached to carbonyl groups, which thereby can be detected using DNP antibodies. After neutralization with $2 \mathrm{M}$ Trisamino/30\% glycerol, the derivatized proteins were acetone precipitated. The precipitation step removes impurities, so that the bands of carbonylated proteins become sharper on the blots. Prior to electrophoresis $\left(20 \mu \mathrm{g}\right.$ undenatured protein well-loading ${ }^{-1}$ on Tris- $\mathrm{HCl}$ $12.5 \%$ gels; criterion-precasted gels, Bio Rad), the precipitated proteins were solubilized in an appropriate volume of sample buffer. Blotting was performed as described above. Non-specific binding sites were blocked with $0.5 \%$ BSA in PBS (pH 7.4) with $0.01 \% \mathrm{v} / \mathrm{v}$ Tween-20 at $4{ }^{\circ} \mathrm{C}$ overnight. Probing with the DNP serum (polyclonal anti-rabbit V0401, Sigma Aldrich) diluted 1:4000 in $0.5 \%$ BSA in PBS (pH 7.4) with $0.01 \%$ $\mathrm{v} / \mathrm{v}$ Tween-20 was carried out for $1 \mathrm{~h}$ at room temperature, the membranes were washed, and then were incubated with secondary serum (swine anti-rabbit IG, Dakocytomation A/S) diluted 1:10 000 in PBS (pH 7.4) with $0.01 \% \mathrm{v} / \mathrm{v}$ Tween-20 for another hour at room temperature. After the membranes had been washed, the proteins were visualized and the carbonylation level (lane staining intensity) was quantified as described above. The membranes with the DNPHderivatized proteins were then washed, re-blocked with $10 \%$ w/v fat-free milk in PBS (pH 7.4) with $0.01 \%$ $\mathrm{v} / \mathrm{v}$ Tween-20 at room temperature for $1.5 \mathrm{~h}$, probed for $\beta$-actin, and the $\beta$-actin was then visualized and quantified in the same way as described above.
Statistical analysis. Sexual maturation, fertilisation frequency, fecundity and ecdysteroid levels (analysis between treatments) were analysed using 2-way ANOVA. Ecdysteroid levels between sexes, mortality, females with dead eggs and intrinsic rate of increase did not display a homogenous variance, and transformations of data were not successful. Hence, data were analysed using the non-parametric Kruskal-Wallis test, and, in cases of further analysis, Mann-Whitney $U$-tests were performed with Bonferroni corrections (SPSS 11.0 software, SPSS Inc.). Mortality and females with dead eggs were additionally analysed using $F$-ratio tests. In all analyses, each microcosm was treated as 1 replicate. Prior to statistical analyses, HSP60 band intensity data and carbonylation lane intensity data for each sample were normalised to the corresponding $\beta$-actin band intensity data, by calculating HSP60/ $\beta$-actin and carbonylation level/ $\beta$-actin ratios. The ratio of actin, a housekeeping gene product, in relation to the total protein amount in a sample is believed to be constant, and actin should thus be suitable for correcting minor loading and/or transfer differences between wells on a gel. It has been used as an internal loading control in Western blots (e.g. Lyons et al. 2003, Prevodnik et al. 2007). Coomassie staining of the gels was also done for visual confirmation of the loading equality between wells. Although temperature and ecdysteroid levels have been shown to affect actin expression in some crustaceans (El Haj et al. 1997, Whiteley et al. 1997), this does not appear to have been the case in Monoporeia affinis, given the conditions in the experiment. Both protein loading and actin levels were comparable in all gel tracks, regardless of treatment. Thus, it should be justified to do actin normalizations. Using $\mathrm{R}$ software (R Core Development Team), ANOVA was applied. We assumed a normal error distribution, and significance testing was done using $F$-tests.

\section{RESULTS}

\section{Life-stage variables}

Mean adult mortality did not differ statistically between the treatments $(p=0.13$; Fig. 1$)$. However, the variance differed significantly between treatments, with the largest variation in the WTF treatment and the lowest in the LTC treatment. The high adult survival (average $86 \%$ ) in LTC indicates that the amphipods were not significantly stressed by factors other than the ones examined in this study (Fig. 1). Fenarimol did not have any impact on wet weight in either sex or stage of sexual maturation. Increased temperature had a positive effect $(p=0.01)$ on female wet weight, but no effect on male wet weight was recorded (Table 1). 


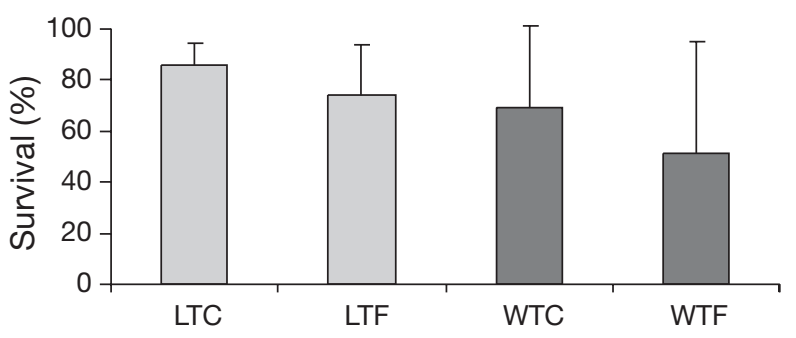

Fig. 1. Monoporeia affinis. Adult survival (mean $+\mathrm{SD})$ per treatment. $\mathrm{N}=12$ microcosms treatment ${ }^{-1}$. LTC: low temperature $\left(4^{\circ} \mathrm{C}\right)$ control; LTF: low temperature and fenarimol; WTC: warm temperature $\left(10^{\circ} \mathrm{C}\right)$ control; WTF: warm temperature and fenarimol

Temperature and fenarimol exposure, alone and in combination, increased the number of females with dead eggs ( $p<0.05$; Fig. 2). Females exposed to a combination of increased water temperature and fenarimol showed a more than 4 -fold higher incidence of dead eggs than females in microcosms exposed to either increased temperature or fenarimol (Fig. 2). The intrinsic rate of increase of the microcosm populations decreased in warm treatments compared to cold treatments ( $p<0.001$; Fig. 3) and a borderline significant decrease in treatments exposed to fenarimol was recorded $(p=0.03$ and $p=0.06$ for cold and warm treatments, respectively). Amphipods exposed to both warm temperature and fenarimol exposure had a negative intrinsic growth rate, signalling a potential population decline.

Warm temperature had a significant negative effect on the fertilisation frequency $(\mathrm{p}<0.05)$ (Fig. 4), fecundity $(p<0.01)$ (Fig. 5), male sexual development $(p<$ $0.05)$ (Fig. 6) and female sexual development $(p<0.05)$ (Fig. 7). Fenarimol exposure resulted in a lower num-

Table 1. Monoporeia affinis. Ecdysteroid equivalents (ng g wet $\mathrm{wt}^{-1}$ ), weight (mg wet wt) and HSP60 expression in $M$. affinis exposed to increased temperature and fenarimol. $\mathrm{N}=4$ to 12 microcosms treatment $^{-1}$. For treatment definitions see Fig. 1. ${ }^{*}$ Statistically different from control $(p<0.05)$

\begin{tabular}{|lrrrrrrrrr|}
\hline & \multicolumn{2}{c}{ LTC } & \multicolumn{2}{c}{ LTF } & \multicolumn{2}{c}{ WTC } & \multicolumn{2}{c|}{ WTF } \\
& Mean & SD & Mean & SD & Mean & SD & Mean & SD \\
\hline Ecdysteroids & & & & & & & & \\
$\quad$ Males III & 4.2 & 1.7 & $2.6^{*}$ & 1.2 & 3.4 & 2.4 & $2.6^{*}$ & 1.1 \\
Males I & 42.8 & 20.2 & 38.8 & 13.2 & 39.8 & 34.1 & 24.9 & 11.5 \\
Females & 40.6 & 16.3 & 43.3 & 15.9 & 30.3 & 14.1 & 38.4 & 9.9 \\
Weight & & & & & & & & \\
$\quad$ Males III & 11.6 & 0.9 & 11.9 & 1.0 & 12.9 & 1.8 & 11.7 & 0.7 \\
Males I & 11.0 & 0.7 & 12.0 & 1.0 & 12.2 & 0.7 & 11.8 & 0.9 \\
Females & 11.6 & 1.0 & 12.9 & 0.8 & $13.3^{*}$ & 0.8 & $13.0^{*}$ & 1.3 \\
HSP60 & & & & & & & & \\
$\quad$ Males III & 1.1 & 0.6 & $2.1^{*}$ & 0.9 & - & - & - & - \\
Males I & 1.4 & 0.5 & $0.3^{*}$ & 0.6 & 1.6 & 1.3 & 1.2 & 0.5 \\
Females & 0.5 & 0.3 & 0.3 & 0.3 & 0.4 & 0.5 & 0.1 & 0.1 \\
\hline
\end{tabular}

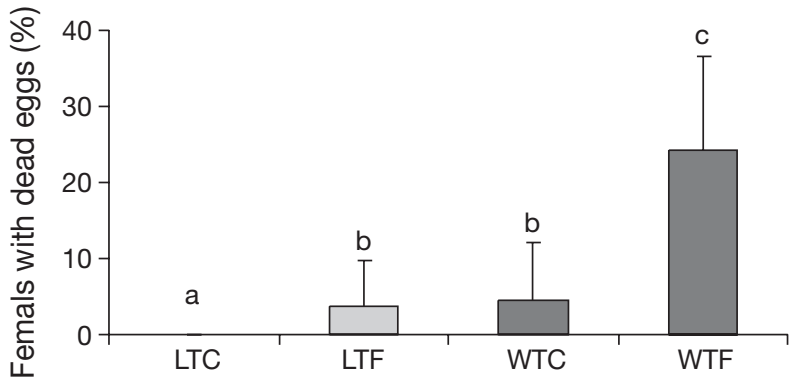

Fig. 2. Monoporeia affinis. Females with dead eggs (mean + SD) per treatment. Different letters indicate means that differed significantly ( $p<0.05$ ); $\mathrm{N}=8$ to 12 microcosms treatment $^{-1}$. For treatment definitions see Fig. 1

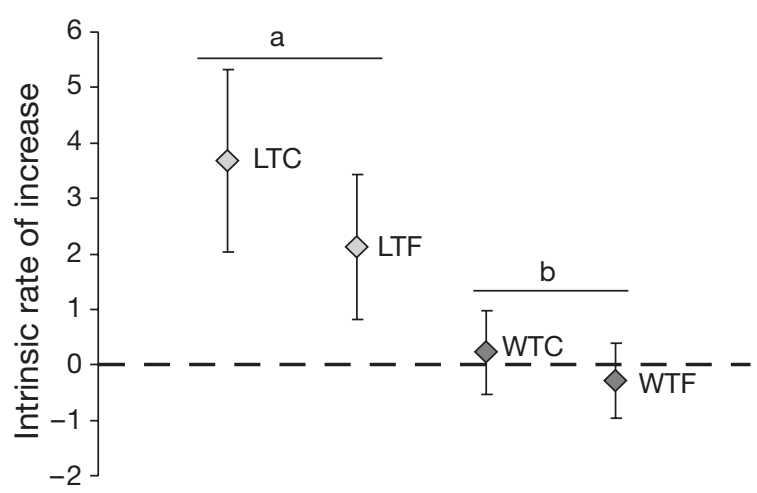

Fig. 3. Monoporeia affinis. The intrinsic rate of increase (mean $\pm \mathrm{SD}$ ) for each treatment. $\mathrm{N}=8$ to 12 microcosms treatment $^{-1}$. Different letters indicate means that differed significantly $(p<0.001)$. For treatment definitions see Fig. 1

ber of fertilised females, although the decrease was not statistically significant ( $p=0.09$ ) (Fig. 4), and a reduced fecundity $(p<0.05)$ (Fig. 5). Fenarimol exposure did not affect the proportion of sexually mature males or females (Figs. $6 \&$ 7), but a trend towards decreased mating ability in males (measured as the number of fertilised females per sexually mature male) was observed (data not shown).

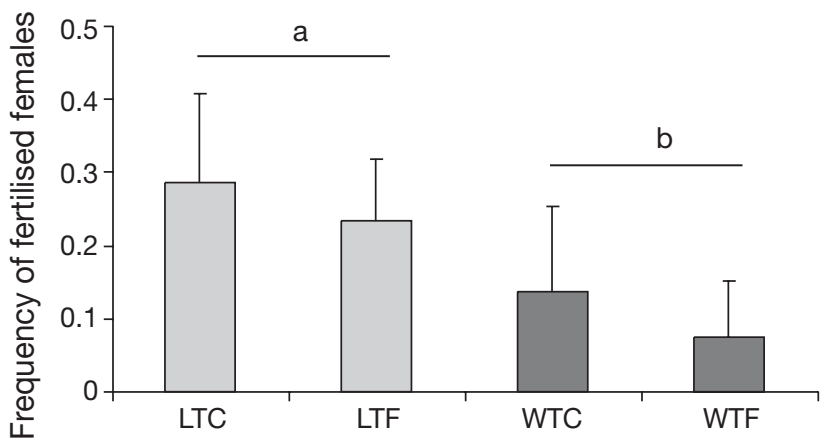

Fig. 4. Monoporeia affinis. Frequency (mean $+\mathrm{SD}$ ) of fertilised females in each treatment. $\mathrm{N}=7$ to 12 microcosms treatment $^{-1}$. Different letters indicate means that differed significantly $(p<0.05)$. For treatment definitions see Fig. 1 


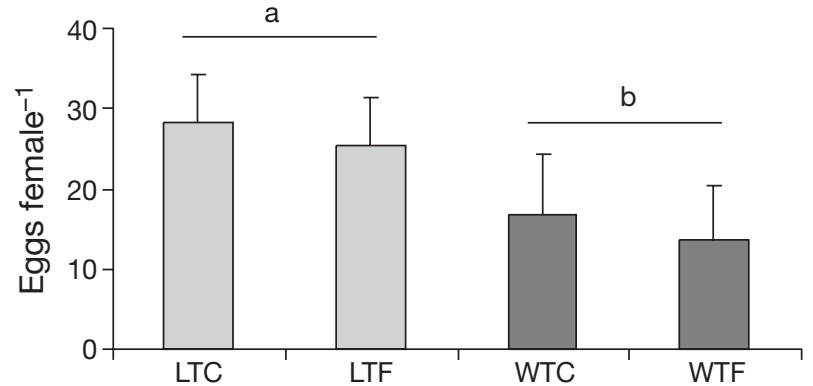

Fig. 5. Monoporeia affinis. Fecundity (eggs female ${ }^{-1}$; mean + $\mathrm{SD}$ ) in each treatment. $\mathrm{N}=4$ to 12 microcosms treatment ${ }^{-1}$. Different letters indicate means that differed significantly $(p<0.05)$. For treatment definitions see Fig. 1

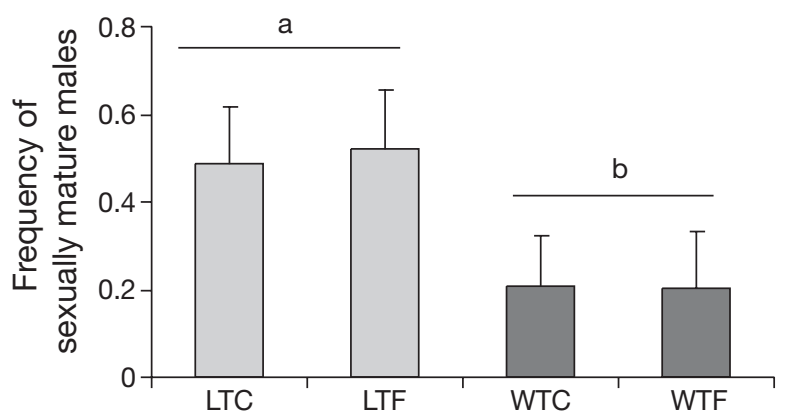

Fig. 6. Monoporeia affinis. Frequency (mean $+\mathrm{SD}$ ) of sexually mature males in each treatment. Different letters indicate means that differed significantly $(p<0.05)$. For treatment definitions see Fig. 1

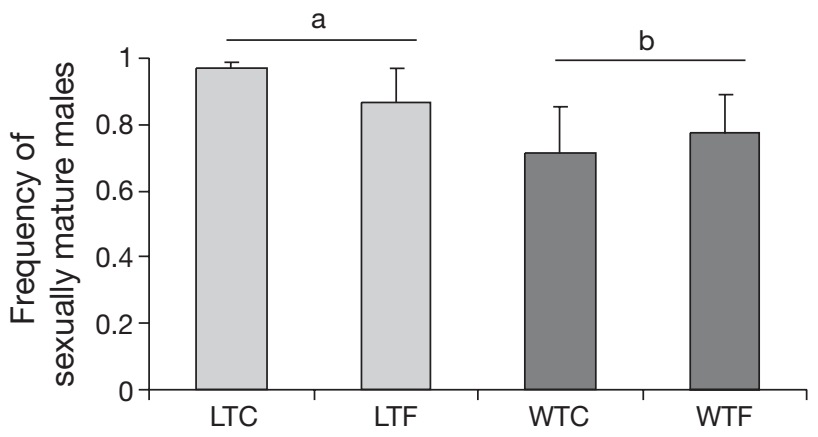

Fig. 7. Monoporeia affinis. Frequency (mean $+\mathrm{SD}$ ) of sexually mature females in each treatment. $\mathrm{N}=7$ to 12 microcosms treatment $^{-1}$. Different letters indicate means that differed significantly $(\mathrm{p}<0.05)$. For treatment definitions see Fig. 1

\section{Biochemical variables}

Sexually mature males had lower levels of ecdysteroids than immature males and females $(p<0.001)$ in the LTC treatment. Fenarimol exposure resulted in significantly decreased levels of ecdysteroids in sexually mature males $(p<0.05)$ (Table 1), but elevated temperature did not elicit any detectable ecdysteroid response. Ecdysteroid levels in immature males and females (Table 1) were not affected by either fenarimol exposure or temperature increase.

The HSP60 antibody recognized 2 bands of 60 and $70 \mathrm{kDa}$, respectively, in Western blots. The bands had different intensities. Only the lower, stronger of the 2, which corresponds to $\sim 60 \mathrm{kDa}$ and is referred to as HSP60, was quantified. The $\beta$-actin antibody recognized a protein of $\sim 40 \mathrm{kDa}$. Sexually mature males in the coldwater series responded to fenarimol with almost double the average expression $(p<0.05)$ (Table 1$)$, while immature males responded with a statistically significant $(\mathrm{p}<0.05)$ (Table 1) drop in average HSP60 expression. No statistically significant difference $\left(F_{1,10}=3.3115\right.$, $\mathrm{p}=0.098$ ) in the level of protein carbonylation was found between control and treated sexually mature males (Stage III), although the level was lower in fenarimol-exposed individuals (data not shown).

\section{DISCUSSION}

Increased temperature and exposure to fenarimol affects the reproduction of Monoporeia affinis negatively, both on a biochemical and organismal level. A combination of high temperature and fenarimol exposure resulted in a more than 4 -fold increase in the number of females with dead eggs compared to exposure to a single stressor (Fig. 2). The increase overrides the added effect of the 2 exposures, which might indicate a synergistic mechanism between increased temperature and fenarimol. In addition, the combination of high temperature and fenarimol exposure was the only treatment to have a negative intrinsic rate of population increase, indicating a potentially reduced population size if amphipods are simultaneously exposed to these stressors in the field (Fig. 3). The fact that the fenarimol content in the sediment was lower in the warm treatment group could suggest that temperature might enhance the effect of fenarimol by increasing the solubility. However, the lower sediment concentration could also indicate a more rapid degradation of fenarimol in warmer conditions (Tomlin 2000).

Increased temperature also had a negative impact on all reproductive variables, i.e. sexual maturation, fertilisation frequency, fecundity and embryogenesis (Figs. $2 \& 4$ to 7). Greater weight was recorded in females exposed to high temperature than was recorded in females subjected to coldwater exposures (Table 1), possibly explained by an increased feeding rate in an environment with an abundance of food. A rise in temperature of $3.2^{\circ} \mathrm{C}$ would increase the oxygen consumption of the amphipods by approximately 20 to $25 \%$ (Schmidt-Nielsen 1997). Despite the greater weight recorded in warm treatments, the female gonads were less developed than those in cold treatments and the 
fertilisation frequency was lower (Figs. 4 \& 7). The higher temperature could affect the lipid metabolism in these stenotherm amphipods and, hence, negatively affect gonad development and thereby also the fertilisation frequency. As we were unable to do histological preparations of the gonads, this remains speculation; however, a previous finding that increased temperature delays mating in this species supports this hypothesis (Eriksson Wiklund \& Sundelin 2001).

Fenarimol exposure resulted in a statistically significant reduction in fecundity (Fig. 5) and a borderline significant decrease in the intrinsic rate of increase (Fig. 3). A trend towards fewer fertilised females per male and number of fertilised females could also be seen. Although not all of them are statistically significant, the results presented here give support to earlier findings that fenarimol impairs reproduction of Monoporeia affinis (Jacobson \& Sundelin 2006), with repercussions on the next generation. Most crustacean species have chemoreceptors in terms of aesthetascs on the segments of antennulae. The lower number of fertilised females per male suggests that there is a hindrance in the fertilisation process. This could be due to impairment of both sexual maturation and mating behaviour. Different contaminants have been shown to affect the male response to female pheromones in $M$. affinis (A. S. Krång, Dept. of Marine Ecology, Gothenburg University, Kristineberg Marine Research Station, pers. comm.). Ecdysteroids are suggested to act as pheromones in crustaceans (Tomaschko 1999), and the decrease in ecdysteroid levels discussed below might have influenced mating success in the present study. Future studies on contaminant effects on the mating behaviour of $M$. affinis could shed some light on this issue.

Sexually mature males showed a decrease in ecdysteroid levels when exposed to fenarimol, a strong indication that fenarimol is an endocrine disruptor in Monoporeia affinis. Since ecdysteroids, in addition to regulating moulting, are linked to both sexual maturation (Subramoniam 2000) and mating behaviour (Tomaschko 1999) in crustaceans, it is possible that the decrease in ecdysteroid levels has influenced the fertilisation success in the present study. Interestingly, sexually mature males differed in response to both sexually immature males and females. Ecdysteroid levels in females and sexually immature males seemed unaffected by fenarimol exposure (Table 1). During the last moult, when males become sexually mature, they lose the ability to feed due to deformed mouthparts (Segerstråle 1937). Hence, males are restricted to stored energy. By consuming these lipids, fat-soluble contaminants can be released and exert toxic effects. In female crustaceans, a higher proportion of contaminants is suggested to be bound to lipids (Oberdorster et al. 2000, Cary et al. 2004). The difference in response to fenarimol could also reflect a difference in ecdysteroid function between sexes and between sexual stages. These results clearly demonstrate the importance of separating specimens in different reproductive stages when analysing reproductive hormones such as ecdysteroids.

Expression of HSP60 in Monoporeia affinis was also dependent upon the gender and sexual developmental stage (Table 1). In fenarimol-exposed sexually mature males, the expression was elevated relative to those amphipods in the control, while in fenarimol-exposed immature males, it was lowered. Fenarimol-exposed immature males in high temperature showed a smaller decrease in HSP60 expression relative to controls than did those in cold temperature, which is consistent with the heat-inducible function of HSPs. Control males of both developmental stages had a higher average HSP60 expression than control females. In females, no clear effect of temperature or fenarimol was observed. HSP60 expression is used as a general marker of stress in this specific case, and we have not explored the mechanisms of HSP60 expression in the present study. The carbonylation level of the proteins in the fenarimol-exposed sexually mature males was, indeed, elevated compared to that in the controls, although not a significant change, indicating an oxidative stress response in sexually mature male $M$. affinis. A larger sample size that would reduce the variance in the carbonylation data could perhaps shed more light on the issue of oxidative stress linked to fenarimol.

During autumn, October temperatures as high as $9.4^{\circ} \mathrm{C}$ have been recorded above the sediment surface at monitoring stations in the Baltic Sea at $40 \mathrm{~m}$ depth, by the Swedish Meteorological and Hydrological Institute (SHARK database, www.smhi.se). In climate models for the Baltic Sea, the predicted average temperature in the surface seawater will increase by $2.6^{\circ} \mathrm{C}$ by the year 2100 (Meier 2002). According to this model, the maximum warming will occur during autumn, at 20 to $50 \mathrm{~m}$ depth, due to higher wind speeds. Due to more or less permanent oxygen deficiency at depths below $50 \mathrm{~m}$ in the Baltic, the 20 to $50 \mathrm{~m}$ zone is the preferred living depth of Monoporeia affinis. Furthermore, this temperature maximum occurs in autumn, during the temperature-sensitive gonad maturation period (for details see 'Materials and methods'), making it highly likely that $M$. affinis will be affected by such warming of the Baltic Sea. Thus, $M$. affinis could find itself trapped between the warmer shallow areas and the oxygen-depleted deeper areas. As shown by Eriksson Wiklund \& Sundelin (2001) M. affinis embryogenesis is highly susceptible to disturbance from low oxygen levels. $M$. affinis is, on the other hand, a glacial relict that, in the past, has managed to adapt to a changing 
environment (Segerstråle 1976). However, today it might have to adapt at a much quicker pace than ever before if it is to survive and remain in this ecosystem.

Acknowledgements. We thank E. S. Chang at the University of California (Bodega Bay, CA, USA) for providing the antibodies, Stockholm Marine Research Center for funding and T. Hansson and Z. Kukulska for practical support with the microcosms.

\section{LITERATURE CITED}

Almroth BC, Sturve J, Berglund A, Förlin L (2005) Oxidative damage in eelpout (Zoarces viviparous), measured as protein carbonyls and TBARS, as biomarkers. Aquat Toxicol 73:171-180

Bajramović JJ, Bsibsi M, Geutskens SB, Hassankhan R and others (2000) Differential expression of stress proteins in human adult astrocytes in response to cytokines. J Neuroimmunol 106:14-22

Cary TL, Chandler GT, Volz DC, Walse SS, Ferry JL (2004) Phenylpyrazole insecticide fipronil induces male infertility in the estuarine meiobenthic crustacean Amphiascus tenuiremis. Environ Sci Technol 38:522-528

Chang ES, O'Connor JD (1979) Arthropod molting hormones. In: Jaffe BM, Beherman HR (eds) Methods of hormone radioimmunoassay. Academic, New York, p 797-814

Cossins AR, Bowler K (1987) Temperature biology of animals. Chapman \& Hall, London

Dalle-Donne I, Giustarini D, Colombo R, Rossu R, Milzani A (2003) Protein carbonylation in human diseases. Trends Mol Med 9:169-176

Del Ramo J, Días-Mayans J, Torreblanca A, Núñes A (1987) Effects of temperature on the acute toxicity of heavy metals $(\mathrm{Cr}, \mathrm{Cd}$ and $\mathrm{Hg})$ to the freshwater crayfish, Procambarus Clarkii (Girard). Bull Environ Contam Toxicol 38:736-741

Donner KO, Lindstrom A, Lindstrom M (1987) Seasonal variation in the vertical migration of Pontoporeia affinis (Crustacea, Amphipoda). Ann Zool Fenn 24:305-313

El Haj AJ, Tamone SL, Peake M, Sreenivasula Reddy P, Chang ES (1997) An ecdysteroid-responsive gene in a lobster-a potential crustacean member of the steroid hormone receptor superfamily. Gene 201:127-135

Eriksson Wiklund AK, Sundelin B (2001) Impaired reproduction in the amphipods Monoporeia affinis and Pontoporeia femorata as a result of moderate hypoxia and increased temperature. Mar Ecol Prog Ser 222:131-141

$>$ Feder ME, Hoffmann GE (1999) Heat-shock proteins, molecular chaperones, and the stress response: evolutionary and ecological physiology. Annu Rev Physiol 61:243-282

Grabarczyk M, Kopec Szlezak J (1992) Protective action of vitamin $\mathrm{E}$ on the subcellular structures of lymphocytes intoxicated with pesticides in vitro. Mater Med Pol 24: 237-239

> Jacobson T, Sundelin B (2006) Reproductive effects of the endocrine disruptor fenarimol on a Baltic amphipod Monoporeia affinis. Environ Toxicol Chem 25:1126-1131

Lee YJ, Shacter E (1995) Role of carbohydrates in oxidative modification of fibrinogene and other plasma proteins. Arch Biochem Biophys 321:175-181

Levine RL, Garland D, Oliver CN, Amici A and others (1990)

Editorial responsibility: Otto Kinne,

Oldendorf/Luhe, Germany
Determination of carbonyl content in oxidatively modified proteins. Methods Enzymol 186:464-478

Lyons C, Dowling V, Tedengren M, Gardestrom J and others (2003) Variability of heat shock proteins and glutathione S-transferase in gill and digestive gland of blue mussel Mytilus edilus. Mar Environ Res 56:585-597

Meier HEM (2002) Regional ocean climate simulations with a 3D ice-ocean model for the Baltic Sea. Part 1: model experiments and results for temperature and salinity. Clim Dyn 19:237-253

> Mu X, Leblanc GA (2002) Environmental antiecdysteroids alter embryo development in the crustacean Daphnia magna. J Exp Zool 292:287-292

Mu X, Leblanc GA (2004) Synergistic interaction of endocrine-disrupting chemicals: model development using an ecdysone receptor antagonist and a hormone synthesis inhibitor. Environ Toxicol Chem 23:1085-1091

Oberdorster E, Brouwer M, Hoexum-Brouwer T, Manning S, McLachlan J (2000) Long-term pyrene exposure of grass shrimp, Palaemonetes pugio, affects molting, and reproduction of exposed males and offspring of exposed females. Environ Health Perspect 108:641-646

Prevodnik A, Lilja K, Bollner T (2007) Benzo[a]pyrene up-regulates the expression of the proliferating cell nuclear antigen (PCNA) and multixenobiotic resistance polyglycoprotein (P-gp) in Baltic Sea blue mussels (Mytilus edulis L.). Comp Biochem Physiol C 145:265-274

Radák Z, Takahasi R, Kumiyama A, Nakamoto H, Ohno H, Ookawara T, Goto S (2002) Effect of ageing and late onset dietary restriction on antioxidant enzymes and proteasome activities, and protein carbonylation of rat skeletal muscle and tendon. Exp Gerontol 37:1423-1428

Schmidt-Nielsen K (1997) Animal physiology: adaptation and environment, 5th edn. Cambridge University Press, Cambridge

Segerstråle SG (1937) Studien über die Bodentierwelt in südfinnländishen Küstengewässern. III. Zur Morphologie des Amphipoden Pontoporeia affinis, nebst einer Revision der Pontoporeia-Systematik. Commentat Biol Soc Sci Fenn $7: 1-183$

Segerstråle SG (1976) Proglacial lakes and the dispersal of glacial relicts. Commentat Biol Soc Sci Fenn 83:3-15

Sogorb A, Andreu-Moliner ES, Almar MM, del Ramo J, Núñes A (1988) Temperature-toxicity relationships of fluvalinate (synthetic pyrethroid) on Procambarus clarkii (Girard) under laboratory conditions. Bull Environ Contam Toxicol 40:13-17

Subramoniam T (2000) Crustacean ecdysteroids in reproduction and embryogenesis. Comp Biochem Physiol C 125: $135-156$

Sundelin B, Eriksson AK (1998) Malformations in embryos of the deposit-feeding amphipod Monoporeia affinis in the Baltic Sea. Mar Ecol Prog Ser 171:165-180

Tomaschko KH (1999) Nongenomic effects of ecdysteroids. Arch Insect Biochem Physiol 41:89-98

Tomlin CDS (2000) The pesticide manual, 12th edn. British Crop Protection Agency, Surrey, p 380-381

Whiteley NM, Taylor EW, El Haj AJ (1997) Seasonal and latitudinal adaptations to temperature in crustaceans. J Therm Biol 22:419-427

Williams DR, Fisher MJ, Rees HH (2000) Characterization of ecdysteroid 26-hydroxylase: an enzyme involved in molting hormone inactivation. Arch Biochem Biophys 376: 389-398

Submitted: June 13, 2007; Accepted: December 19, 2007

Proofs received from author(s): January 29, 2008 